А. В. Себелева, К. А. Чернопиская

ОСОБЕННОСТИ ПРОФЕССИОНАЛЬНОГО ОБРАЗОВАНИЯ В РАМКАХ ГОСУДАРСТВЕННОГО НАЦИОНАЛЬНОГО ПРОЕКТА ПО ВОЗРОЖДЕНИЮ РОДНЫХ ЯЗЫКОВ И ЛИТЕРАТУР

A. V. Sebeleva, K. A. Chernopiskaya

\title{
VOCATIONAL EDUCATION WITHIN THE FRAMEWORK OF STATE NATIONAL PROJECT FOR REVITALIZATION OF INDIGENOUS LANGUAGES AND LITERATURES
}

\begin{abstract}
Аннотация. Целью авторов статьи стала попытка описать один из этапов прохождения производственной педагогической практики студентов направления подготовки 44.04.01 «Педагогическое образование» (уровень магистратуры), направленности (профиля) «Хантыйская филология», где была разработана и апробирована «сквозная» программа по родной литературе для обучающихся основного общего образования. В рамках государственного национального проекта по возрождению родных языков и литератур видится актуальным подготовить выпускников для преподавания дисциплины «Родной язык и родная литература» в общеобразовательной школе. Предметом исследования являются необходимые педагогические и филологические компетенции, которые следует учитывать в процессе профессионального обучения. В основу методологии исследования легли общенаучные принципы объективности, целостности, конкретности. Не менее важен в данной работе лежащий в основе культурно-исторического метода изучения литературы принцип историзма, требующий рассмотрения понятия жанров произведений писателей Югры. Принцип системности позволил целостно и всесторонне проанализировать заявленную проблему, устранить фрагментарность в изложении. Посредством типологического и системноаналитического методов было проанализировано большое количество материала по обозначенной теме, подведены итоги и сделаны общие выводы. Современное российское пространство высшего образования требует от будущего учителя, проживающего в Ханты-Мансийском автономном округе - Югре, новых знаний в области культуры, языка и литературы обских угров. Это включает в себя фундаментальные изменения в профессиональных задачах, решаемых профессиональным образованием. Поэтому обучение должно адаптироваться в соответствии с требованиями нового контекста.

Ключевые слова: родная литература; родной язык; рабочая программа; государственный национальный проект; ханты; манси; малочисленные народы Севера; обские угры.
\end{abstract}

Abstract. The article describes a stage of teaching practicum taken by Master's students majoring in 44.04.01 Pedagogical Education (Master's Degree program) with the Khanty Philology profile, where a 'cross-cutting' native literature program was developed and tested for general education students. In the framework of the state national project for revitalization of native indigenous languages and literatures, it appears relevant to train educators who can teach indigenous languages and native literatures in a comprehensive school. This study addressed the teaching and philological competencies that should be acquired in the process of vocational training. The research methodology rooted in the general scientific principles of objectivity, integrity, and concreteness. No less important in this work was the principle of historicism underlying the cultural-historical method of studying literature, which requires consideration of genres of works by Yugra's writers. The systematic principle made it possible to holistically and comprehensively analyze the declared problem, eliminate the fragmentation in its presentation. Using the typological and system-analytical methods, a large amount of material on the studied topic was analyzed. The findings were summarized and the general conclusions were drawn. The modern Russian space of higher education requires new knowledge in the field of culture, language and literature of the $\mathrm{Ob}$ Ugrians from the future teacher living in the Khanty-Mansi Autonomous Okrug - Yugra. This entails fundamental changes in the professional tasks that are solved by vocational education. Therefore, training must adapt to the requirements of the new context.

Keywords: native literature; indigenous language; teaching practicum; state national project; Khanty; Mansi; indigenous peoples of the North; Ob Ugrians.

Сведения об авторах: Себелева Анастасия Валериевна, ORCID 0000-0002-9545-0105, канд. филол. наук, Нижневартовский государственный университет, г. Нижневартовск, Россия, sebelevaa@mail.ru; Чернопиская Кристина Александровна, Нижневартовский государственный университет, г. Нижневартовск, Россия, putenihinak@mail.ru 
About the authors: Sebeleva Anastasia Valerievna, ORCID 0000-0002-9545-0105, Ph.D., Nizhnevartovsk State University, Nizhnevartovsk, Russia, sebelevaa@mail.ru; Chernopiskaya Kristina Aleksandrovna, Nizhnevartovsk State University, Nizhnevartovsk, Russia, putenihinak@mail.ru

Одними из основных положений социально-экономического и политического развития общества Российской Федерации является сохранение культурных и нравственных ценностей многонационального народа страны, национальной самоидентификации всех ее граждан, а также укрепление духовного единства общества. Культурные и нравственные ценности, представляющие особую социальную значимость для граждан страны, объединяют народности в единую российскую нацию. Они создают основу ее духовного единства, заметного в патриотическом отношении людей к своей большой и малой родине, к ее истории и культуре, к природе.

Сохранение культурных и нравственных ценностей определяет поведение граждан в обычной жизни и на производстве, обуславливает их готовность к реализации новейших ведущих открытий современной науки и техники для совершенствования общества, противодействию культурного доминирования со стороны других национальных обществ. Все сказанное выше гарантирует сохранение самобытности, определяет духовные возможности развития России на далекое будущее.

Об этом свидетельствует и выступление президента РФ в Пятигорске 15 августа 2018 г. Владимир Владимирович Путин отметил, что программу сохранения национальных языков народов России нужно возрождать на современной основе. Закон, позволяющий школьникам и их родителям выбирать родной язык для изучения, вступил в силу 14 августа 2018 г. [16]. Как поясняют авторы инициативы, теперь школьникам не придется изучать в качестве родного тот язык, который родным для них не является. Но есть и оборотная сторона медали. Этот же закон дает право представителям разных этносов выбрать для изучения свой родной язык. Мы говорим сейчас о народах ханты и манси, чей язык и культура в целом находятся на грани исчезновения.

В начале XX в. были изданы первичные художественные произведения на языке обских угров. Они появились в номерах рукописного фольклорно-этнографического и литературно-искусствоведческого журнала «Советский Север». Этот журнал публиковался в Остяко-Вогульском национальном педагогическом училище студентами-энтузиастами общества национального творчества под управлением педагогов В. Сенкевич и И. Гудкова. Позднее В. Сенкевич переведет на русский язык некоторые лирические произведения Г. Лазарева [14], Д. Тарлина, Л. Вайветкина и других начинающих авторов. В военный период югорская литература не появлялась на страницах литературных журналов. Это было связано с рядом причин: во-первых, многие литераторы погибли на войне; во-вторых, послевоенная разруха диктовала свои условия - восстановление страны. Из студентов, членов общества национального творчества, только Г. Лазарев изредка публиковал свои произведения в газете «Ленинская правда». Подъем литературно-художественного творчества обских угров происходит в 60-е гг. XX в. благодаря деятельности Ленинградского государственного педагогического института им. А. Герцена. Созданный на его базе Институт народов Севера и в настоящее занимает основное место в исследованиях произведений малочисленных народов [5].

Другая тенденция проявляется в том, что произведения народов ханты и манси мало читаются, не имеют своей аудитории, поэтому редко печатаются. Это обосновывает повсеместный переход на всех пластах жизни народов обских угров на русский язык, что, естественно, не способствует развитию родного языка. Неизбежным следствием данной тенденции становится и кризис национального сознания, и ограничение публикаций художественных текстов на родном языке народов ханты и манси, и сокращение научных исследований в области угорской литературы и языка. Эта ситуация продиктовала новые условия для восстановления научного интереса к культуре, истории, языку, фольклору, литературе народов ханты и манси. Для решения данной проблемы были организованы центры по изучению национальной литературы и языка обско-угорских народов в Санкт-Петербурге, Тюмени, Салехарде и Ханты-Мансийске.

Ученые, исследующие творчество угорских поэтов и прозаиков, рефлексирующие над процессами эволюции национальной литературы, в настоящий момент опубликовали значимые научные работы. Это и монография Е. Роговера, С. Нестеровой «Творчество Еремея Айпина» [19], и научные работы Н. Цымбалистенко «Север есть Север» [21], «Север учил, ничего не тая... (Творчество Романа Ругина)» [22], «Ямал литературный. От мифологии к постмодернизму» [23], и монография О. Лагуновой «Феномен творчества русскоязычных писателей ненцев и ханты послед- 
ней трети XX века: Ю. Вэлла, Е. Айпин, А. Неркаги» [13], и одна из работ В. Огрызко «В сжимающемся пространстве: портрет на фоне безумной эпохи» [17] о Е. Айпине и его творчестве, и монографии Е. Косинцевой «Женские образы в хантыйской литературе» [10], в том числе монография, изданная в соавторстве с Н. Куренковой, «"Все в этом мире от Бога...”: роман Е. Айпина “Божья матерь в кровавых снегах" " [11], и совместная работа А. Себелевой и Е. Рымаревой о русскоговорящей писательнице Югорского края М. Анисимковой [20] и др.

Угорскую литературу изучают не только отечественные, но и зарубежные исследователи. Зарубежные ученые, такие как П. Домокош [6], А. Шаррен [25], М. Чепреги [24] и др., вводят художественную словесность обских угров в систему финно-угорских литератур России и мира, однако маркируя ее национальный колорит. Это увеличивает пути этнокультурного взаимодействия и ставит исследования на новый уровень. Современные русские филологи Е. Роговер, Н. Цымбалистенко, О. Лагунова, Е. Косинцева и другие обрисовывают главные направления изменения хантыйской и мансийской художественной словесности. В область их исследований входит изучение художественного творчества ведущих поэтов и прозаиков Югры, историкокультурный и сравнительно-сопоставительный анализ произведений. Вопросы поэтики литературы ханты и манси раскрываются в работах А. Ващенко [3], Г. Данилиной [4], А. Жулевой [8], Е. Каргаполова [9], Т. Молдановой [15] и др.

Изучение художественного языка литературы обских угров считается самым интенсивно развивающимся направлением современной лингвистики. Современными исследованиями в области анализа художественной речи являются научные труды А. Бельковой, которая анализирует язык произведений В. Мазина [2] и Н. Коняева [1], в области диалектологии монографии А. Шиянова о шурышкарском диалекте [26], А. Каксина о казымском диалекте [9], М. Чепреги о сургутском диалекте [24] и др.

Согласно концепции поддержки и развития чтения в Ханты-Мансийском автономном округе - Югре на 2018-2025 гг., «особенностью Ханты-Мансийского автономного округа является то, что округ является исконным местом проживания коренных малочисленных народов ханты, манси и ненцев. В регионе сформирована правовая база, способствующая поддержке национальных (родных) языков коренных малочисленных народов, изучению родных языков, литературы и культуры коренных малочисленных народов Севера. Хантыйский (казымский, сургутский, ваховский диалекты), мансийский, ненецкий языки изучают в детских садах, школах и учреждениях дополнительного образования Березовского, Октябрьского, Белоярского, Нефтеюганского, Нижневартовского, Сургутского, Кондинского, Ханты-Мансийского районов, городов Лангепаса, ХантыМансийска» [7].

Приказами Министерства образования и науки Российской Федерации от 31.12.2015 г. № 1576, 1577, 1578 в ФГОС начального общего (далее - НОО), основного общего (далее - ООО), среднего общего образования (далее - $\mathrm{COO}$ ) внесены изменения, которые определяют выделение отдельных предметных областей по русскому языку и литературе, родному языку и родной литературе с целью воплощения в полном объеме прав обучающихся на изучение родного языка.

В соответствии с ФГОС НОО и ООО предметная область «Родной язык и литературное чтение на родном языке», «Родной язык и родная литература» являются обязательными для изучения.

ФГОС ООО содержит требования к предметным результатам освоения ООП на уровне образования и нормативно не определяет количество часов на изучение отдельных предметов, поэтому количество часов на изучение данных предметов образовательное учреждение определяет самостоятельно в соответствии с особенностями осуществляемой образовательной деятельности и желаемыми результатами.

В свете изменений в Федеральном образовательном стандарте общей образовательной школы вузы, где реализуются педагогические направления подготовки, также должны внести изменения в преподавание методических дисциплин. Для создания вузовской методической базы в этой области необходимо всестороннее изучение программ школьных учебно-методических курсов. Материалы данной программы являются основой вузовского курса «Методика преподавания родной литературы» и частью задания при прохождении производственной педагогической практики. В программе прослеживается принцип последовательного изучения и углубления знания по родной литературе по классам. 
Так, нами были проанализированы учебники для 5-8 классов таких аторов, как В.Я. Коровина, Т.Ф. Курдюмова, Г.С. Меркин, А.Г. Кутузов, В.Г. Маранцман. Рабочие программы и учебники входят в состав учебно-методического комплекса (УМК). Каждый УМК создается в соответствии с федеральным компонентом государственного образовательного стандарта, который утвержден приказом Министерства образования и науки РФ. В государственном образовательном стандарте прописаны произведения литературы, которые являются обязательными для изучения в школьном курсе литературы.

Данные учебники рекомендованы к использованию при реализации имеющих государственную аккредитацию образовательных программ начального общего, основного общего, среднего общего образования. Список учебников был утвержден приказом Министерства образования и науки РФ № 253 от 31.03.2014 г.

Общим для программ этих авторов является историко-литературный принцип организации материала. Кроме историко-литературного принципа существуют еще литературоведческий и тематический принципы, которые нашли отражение в учебниках других авторов (А.Г. Кутузов, В.Г. Маранцман).

В программы и учебники по литературе включены вершинные произведения, которые соответствуют возможностям познания учеников. Школьное литературное образование концентрично, т. е. оно состоит из двух больших концентров - 5-9-й и 10-11-й классы. Первый концентр состоит из трех возрастных групп (5-6-й, 7-8-й и 9-й классы). Для первой группы характерно активное восприятие текста, но в то же время и недостаточность владения собственной техникой чтения. Для второй группы свойственно владение техникой чтения и истолкование прочитанного. Наибольшее внимание чтению вслух уделяется в первой группе. Со второй группой предполагается не только активное чтение, но и углубленное толкование художественного произведения. 9-й класс - это подведение итогов обучения предыдущих лет, расширенные сведения о биографиях писателей. Во время данного периода ребята знакомятся с темами, проблемами, авторами, с которыми им еще не приходилось иметь дело ранее. Используется работа с критикой, мемуарами, справочной литературой. В 10-11-х классах изучают художественную литературу на литературноисторической основе.

Многие педагоги отмечают, что концентричность учебной программы по литературе уже не актуальна. Это связано с внесением изменений в основную образовательную доктрину государства, а именно - дать всем учащимся полное среднее образование [12].

Концентричность программ была направлена на то, чтобы те ученики, которые продолжат свое обучение в профессионально-технических учебных заведениях после 9-го класса, получили представления о литературе во всем ее многообразии. Сейчас данная потребность не актуальна. Многие педагоги говорят о целесообразности возврата к линейной программе, которая будет способствовать наилучшему освоению курса литературы учащимися школ.

Следующее, что объединяет проанализированные УМК, - главная идея трех программ. Она заключается в последовательном освоении тем, согласно историко-литературному принципу: изучение литературы от мифа к фольклорному жанру, от фольклорного жанра - к литературе Древней Руси, от древнерусской литературы - к русской литературе XVIII, XIX и XX веков.

У каждого курса есть своя проблема, которая рассматривается на протяжении всего обучения: 5-й класс - книга, 6-й класс - автор и произведение, 7-й класс - особенность писательской работы, 8-й класс - связь истории и литературы, 9-й класс - значение литературы в духовном становлении личности.

Авторы программ стараются избегать строгих регламентаций. Они дают право выбора педагогам определить перечень произведений, которые подлежат чтению и изучению, и перечень самостоятельно изучаемых и обсуждаемых. Все это называется вариативностью учебно-познавательного процесса.

Таким образом, возникла необходимость в подготовке учителей родной литературы и в разработке учебно-методических комплексов, которые могут быть реализованы в рамках курсов в высшей школе и апробированы на производственной педагогической практике студентов направления подготовки 44.04.01 «Педагогическое образование» (уровень магистратуры), направленности (профиля) «Хантыйская филология». 
Проанализировав школьные программы по литературе, можно заключить, что на изучение русской литературы в школе отводится недостаточное количество часов, а родная литература не изучается вовсе. Так, дети, проживающие на территории Югры, не знают даже основ культуры народов ханты и манси. Думается, что проживая на территории обских угров, мы должны хотя бы поверхностно знакомить детей с их мифологией и художественным творчеством. Но существует несколько препятствий этому: во-первых, малое количество часов на изучении литературы вообще, во-вторых, отсутствие специалистов в области ханты-мансийской филологии в Нижневартовске, в-третьих, отсутствие потребности в изучении данной литературы у школьников и студентов. И если первые два можно попытаться устранить, то привить любовь к казалось бы чуждой для детей культуре и литературе невозможно. И именно этому вопросу, на наш взгляд, мы должны уделить наибольшее внимание. Чтобы принять и полюбить эту литературу, нужно ее понимать, следовательно, надо развивать читательскую компетентность обучающихся. Читательская компетентность понимается как совокупность знаний, навыков, позволяющих человеку отбирать, понимать, организовывать информацию, представленную в печатной (письменной) форме, и успешно использовать в личных и общественных целях; она является совокупным личностным качеством, сформированным на базе его интеллектуальных (мыслительных) способностей и личностных свойств. Читательская компетентность основывается на междисциплинарных, межпредметных знаниях и осуществляется через множество умений - искать и анализировать информацию, понимать и интерпретировать текст, оценивать и формировать суждения о тексте. Именно эти компетенции формируются у студентов направления подготовки 44.03.01 «Педагогическое образование», направленность (профиль) «Филологическое образование» при изучении ряда специальных профильных дисциплин.

Данное понятие сформулировано в соответствии с «Национальной программой поддержки и развития чтения» - главным документом, который определяет политику развития и поддержки чтения в целом по стране. Программа разработана Федеральным агентством по печати и массовым коммуникациям совместно с Российским книжным союзом. Существование подобного документа подтверждает актуальность проблемы. Очевидно, что если она решается на самом высоком уровне, это значит, что она стоит в ряду приоритетных задач государства в области культуры.

Количество часов на изучение каждого предмета образовательная организация определяет самостоятельно в соответствии со спецификой реализуемой основной образовательной программы для достижения планируемых результатов.

Выбор класса-(ов) для изучения предметов образовательная организация определяет самостоятельно аналогично действиям, описанным для уровня начального общего образования.

Образовательная организация вправе самостоятельно разрабатывать и утверждать программы учебных предметов. На сайте «Реестр основных общеобразовательных программ» размещена примерная программа по предмету «Родной язык» для образовательных организаций, реализующих программы основного общего образования, одобренная решением Федерального учебнометодического объединения по общему образованию (протокол от 31.01.2018 г. № 2/18). Данная программа может быть использована в качестве основы для разработки рабочих программ по предмету «Родной язык». Отметим, что примерной программы предмета «Родная литература» на сайте не представлено.

На предметы «Родной язык», «Родная литература» в классном журнале выделяются отдельные страницы. Организация промежуточной аттестации и текущего контроля по данным предметам осуществляются в соответствии с локальными нормативными актами образовательной организации.

ФГОС СОО в отличие от ФГОС ООО указывает, что учебный план СОО должен предусматривать изучение не менее одного учебного предмета из каждой предметной области. Пунктом 18.3.1 приказа Министерства образования и науки Российской Федерации от 17.05.2012 г. № 413 «Об утверждении федерального государственного образовательного стандарта среднего общего образования» (далее - приказ № 413) предметы «Русский язык», «Литература» включены в предметную область «Русский язык и литература», поэтому учебный план СОО должен содержать один предмет из предметной области «Родной язык и родная литература». Это может быть «Русский родной язык» или «Русская родная литература» [16]. 
Пункт 9.2 приказа № 413 указывает, что «предметные результаты изучения предметной области "Родной язык и родная литература" включают предметные результаты учебных предметов: "Родной язык”, “Родная литература" (базовый и углубленный уровень) - требования к предметным результатам освоения базового курса родного языка и родной литературы должны отражать:

1) сформированность понятий о нормах родного языка и применение знаний о них в речевой практике;

2) владение видами речевой деятельности на родном языке, обеспечивающими эффективное взаимодействие с окружающими людьми в ситуациях формального и неформального межличностного и межкультурного общения;

3) сформированность навыков свободного использования коммуникативно-эстетических возможностей родного языка и родной литературы;

4) сформированность понятий и систематизацию научных знаний о родном языке и родной литературе;

5) сформированность навыков проведения различных видов анализа слова (фонетического, морфемного, словообразовательного, лексического, морфологического);

6) обогащение активного и потенциального словарного запаса путем прочтения родной художественной литературы;

7) овладение основными стилистическими ресурсами лексики и фразеологии родного языка, основными нормами родного языка, нормами речевого этикета;

9) сформированность понимания родной литературы как одной из основных национальнокультурных ценностей народа, как особого способа познания жизни;

10) обеспечение культурной самоидентификации, осознание коммуникативно-эстетических возможностей родного языка на основе изучения выдающихся художественных произведений своего народа».

Таким образом, в учебных планах НОО, ООО, СОО обязательно наличие предметных областей «Родной язык и литературное чтение на родном языке», «Родной язык и родная литература» и соответствующих предметов. За образовательными организациями сохраняется самостоятельность в определении количества часов на изучение предметов, осуществлении текущего контроля и промежуточной аттестации обучающихся, использовании методов обучения и образовательных технологий.

Преподавателями и студентами направления подготовки 44.04.01 «Педагогическое образование» (уровень магистратуры), направленности (профиля) «Хантыйская филология» на основе данного анализа была разработана «сквозная» программа изучения родной литературы в вузе с разбивкой по возрастным категориям обучающихся. Цель такой разбивки - формирование профессиональных компетенций будущих учителей по поэтапному обучению в средней общей школе ХМАО-Югры.

В связи с вышесказанным возникает потребность создания рабочей программы для обучающихся 5-8-х классов по предмету «Родная литература», связанная с тем, что к числу наиболее острых относится проблема незнания родной литературы детьми народов ханты и манси. Хантыйскую и мансийскую литературу знают преимущественно люди старшего поколения. Обучение хантыйскому и мансийскому языкам и литературе ведется только в национальных школах округа. В настоящее время численность народов ханты и манси в городах возросла и продолжает увеличиваться. В современных семьях не говорят на хантыйском и мансийском языках, т. к. доля межнациональных браков велика. В то же время потребность в изучении языка и литературы и знакомстве с родной культурой в настоящее время существует.

Преподавателями кафедры при поддержке администрации МБОУ «СШ № 6» г. Нижневартовска была разработана «сквозная» рабочая программа «Родная литература».

Целью рабочей программы по изучению родной литературы является приобщение воспитанников к изучению литературы коренных малочисленных народов Севера через изучение культуры народов ханты и манси. Задачи:

- Изучить историю возникновения и становления литературы Югорского края;

- $\quad$ Рассмотреть творчество отдельных персоналий и формировать целостное представление о литературе Югры как вполне самостоятельного культурного феномена; 
- $\quad$ Ознакомить с историей становления литературы коренных народов Севера, ее жанровой классификацией, сюжетами, мотивами, художественными средствами выражения;

- $\quad$ Сформировать представление о художественном мире провинциального локального текста сквозь призму специфического психологоса;

- $\quad$ Совершенствовать умения и навыки анализа поэтического и прозаического текста как объективной художественной реальности.

Формирование целостной картины мира у обучающихся - важная составляющая. Приступая к изучению новой темы, необходимо показать, как можно раскрыть один и тот же образ окружающего нас мира с помощью слов, звуков, предметов. В этом случае отдельные знания, полученные на занятиях, будут складываться в одну большую «картину-представление», способствующую созданию истинной системы знаний и правильному миропониманию литературы народов ханты и манси. В педагогике под интегрированным занятием подразумевается урок, в котором вокруг одной темы объединяется материал нескольких предметов.

Основой разработки интегрированных уроков является интегративно-тематический подход, обоснованный Г.Ф. Федорцом. В данном подходе за содержательную, методическую и организационную единицу процесса обучения берется не урок, а учебная тема или раздел учебной дисциплины. Положения каждой темы подчинены ведущим идеям, т. е. происходит конкретизация идей предмета в процессе изучения темы. Ведущие идеи учебного предмета - это понятия, законы, принципы, закономерности, теории, которые выражают сущность изучаемого материала, сообщают ему органическую целостность. Следовательно, они выполняют функцию системообразующих связей в содержании учебных предметов, являясь «осью» этого содержания, вокруг которых и происходит объединение, концентрация учебного материала, т. е. ведущие идеи как бы «сшивают» учебные темы в единую систему.

При формировании рабочей программы мы ориентировались на хрестоматии и сборники заданий, рекомендованные к изданию учебно-методической комиссией Обско-угорского института прикладных исследований и разработок.

В результате освоения дисциплины обучающийся должен: знать специфику и закономерности становления региональной литературы как самостоятельного историко-литературного явления; уметь анализировать творчество наиболее значимых представителей литературы Югры; владеть навыками аналитического подхода к изучению художественного текста.

\section{Содержание учебного материала по разделам (темам)}

5-й класс. Жанры хантыйского фольклора. Жанры мансийского фольклора. Поэтика хантыйского фольклора. Поэтика мансийского фольклора. Три типа духов (по К.Ф. Карьялайнен): «домашние», «местные», «всеобщие». Сущность человека, его рождение и смерть согласно представлениям ханты и манси. Синкретизм и религия народа ханты. Сказовое начало в литературе края. Устное народное творчество. Мансийская сказка о медведе и бурундуке, «Деревня охотника», «Сиротка», «Ворона с бусами в ушах». Хантыйская сказочная проза. Анна Митрофановна Конькова «Сантыр и Лэен», «Сорнин Канясь - Золотой Князь», «Глухарь величиной с оленя». Юван Николаевич Шесталов «Сказка о ребеночке-бобреночке», «Героическая песня дяди Сергея». Маргарита Кузьминична Анисимкова «Танья-богатырь», «Оленья шкура». Андрей Семенович Тарханов «Толька». Ольга Александровна Кошманова «Яльвиль». Александр Федорович Слинкин «Общий котел».

6-й класс. Мифология коренных народов Севера. Миф о сотворении земли. Происхождение и эволюция этноса. Материальная и духовная культура. Космологические представления хантов (линейное, этажное членение мира). Категории «особых» лиц: шаман (хант. йолта-ку), сказочник (хант. маньтье-ку), песня-человек (хант. арэхта-ку), сон-человек (хант. улан-ку), плачущий человек (ханm. ель-кy). Культовые дома и святилища. Природа в традиционных обрядах ханты и манси. Этнографический феномен «Медвежьего праздника». Формирование корпуса духов. Двойная природа тотемического предка. Отношения между духами и людьми. Анна Митрофановна Конькова «Вожак Ивыр», «Праздник трясогузки». Юван Николаевич Шесталов «Песня дяди Сергея», «Северный хлеб». Маргарита Кузьминична Анисимкова «Янглал-маа». Светлана Селиверстовна Динисламова «Мама», «С волками жить - по-волчьи выть». Ольга Александровна Кошманова «Лесбег». Александр Федорович Слинкин «Дуб», «С новым годом!». 
7-й класс. Знакомство с жанром послания. Женщина как центр мироздания - ведущий вектор лирики Вагатовой Марии Кузьминичны в произведении «Дочка, доченька!». Динисламова Светлана Селивёрстовна «Я горжусь тобой, родная!», «Полина». Знакомство с жанром баллады. Первые поэтические опыты хантыйского литератора Ругина Романа Прокопьевича «Мальчишеской порой в далекие года...», «Ланги», «Человек ростом с мизинец». Знакомство с жанром лирического стихотворения. Творческая биография мансийского поэта Андрея Семеновича Тарханова. Ранняя лирика «К новорожденному», «Монолог охотника», «О сиротах». Творчество Анисимковой Маргариты Кузьминичны «Невероятные приключения Ерофея Анямова». Шесталов Юван Николаевич - поэт-миротворец. Природа художественного мышления Ювана Шесталова. Анализ произведений «Медвежье слово о журавле», «Сначала была сказка». Анализ художественной формы произведения Коньковой Анны Митрофановны «Рождение кедра». Волдин Владимир Семёнович «Так Молупси»: художественные приемы. Айпин Еремей Данилович - основоположник хантыйской прозы. Природа художественного мышления писателя. Синтез публицистики и мифологии как новый тип построения литературного произведения «Я слушаю Землю». Лазарев Григорий Дмитриевич и идейная направленность произведения «Катание на лосе».

8-й класс. Знакомство с поэтами Югорского края. Мифология и фольклор - источники мотивов и образов лирики Ювана Николаевича Шесталова. Анализ произведений «Если будет Россия...», «Клич журавля», «Синий ветер каслания». Природоцентричная поэзия Тарханова Андрея Семеновича: «Орда», «Седой простор», «Исповедь человека, лишенного детства», «ХантыМансийские холмы». Время и пространство в произведении Айпина Еремея Даниловича «Седой простор». Интеграция пространственно-временных универсалий с мифологическими воззрениями ханты в стихотворениях Володина Владимира Семеновича «Ханты», «Сосновый бор». Художественное своеобразие стихотворения Лазарева Григория Дмитриевича «Лиственница». Динисламова Светлана Селивёрстовна «Я стою у окна. Потихоньку светает»; Карнаухова Светлана Владимировна «Воспоминания детства»: философские размышления авторов о времени и о себе.

\section{Образовательные технологии}

Мультимедийное обучение: вербальные и визуальные материалы представляются синхронно, что способствует оптимально эффективному обучению.

Активные и интерактивные методы обучения: групповое взаимодействие, которое включает в себя учебные дискуссии, выполнение творческих заданий.

Данные методы преподавания повышают способность обучающихся выявлять и структурировать материал, эффективнее и полнее анализировать текст, глубже понять изучаемую литературную эпоху.

Использование средств Интернета для проведения теоретических занятий: онлайнтрансляции чтения текстов профессиональными актерами, интервью с авторами.

Система знаний, полученных обучающимися в процессе изучения курса, позволит им ориентироваться в литературном краеведении, сформирует целостное представление о литературе Югорской земли как самостоятельном культурном явлении. Дисциплина представляет собой опыт систематизации и обобщения историко-литературного, учебного, библиографического материала по изучению истории возникновения и становления литературы Югорского края, творчества отдельных персоналий и предполагает формирование у обучающихся целостного представления о литературе Югры как о самостоятельном историко-литературном явлении, отражающем общие тенденции развития отечественной и мировой культуры.

Данная программа нашла свое отражение в вузовском профессиональном образовании: в учебные планы была внесена дисциплина для направления подготовки 44.03.01 «Педагогическое образование» (уровень бакалавриата), направленность (профиль) «Филологическое образование» «История литературы Югорской земли», а также модернизирована, согласно новым стандартам, рабочая программа дисциплины «Методика обучения и воспитания (по профилю подготовки)» «Особенности преподавания литературы в школах ХМАО-Югры», «Особенности преподавания русского языка в школах ХМАО-Югры». Нижневартовский государственный университет с 2019 г. реализует программу магистратуры по направлению подготовки 44.04.01 «Педагогическое образование», профиль (направленность) «Хантыйская филология», в рамках которой ведется подготовка учителей родного языка и родной литературы. Навыки, приобретенные в ходе разработки 
представленной программы, могут быть применены студентами в ходе изучения дисциплины «Методика преподавания родной литературы» и прохождения различных типов практик.

\section{ЛИТЕРАТУРА}

1. Белькова А. Е. Лексическая актуализация разговорного стиля в структуре повествования югорского прозаика Н. И. Коняева // Вестник угроведения. 2020. Т. 10. № 1. С. 26-33. https://doi.org/10.30624/22204156-2020-10-1-26-33

2. Белькова А. Е. Специфика синонимии как проявление номинативного варьирования в югорской поэзии: на материале творчества Владимира Алексеевича Мазина // Вестник угроведения. 2018. Т. 8. № 1. C. 15-21. https://doi.org/10.30624/2220-4156-2018-8-1-22-27

3. Ващенко А. Бремя особого рода // Литературная Россия. 2006. № 37. URL: https://litrossia.ru/item/1168-oldarchive (дата обращения: 30.09.2019).

4. Данилина Г. Роман Е. Айпина «Ханты, или Звезда Утренней Зари» // Литература Тюменского края / Под ред. Н. А. Рогачевой. Тюмень, 1997. С. 130-144.

5. Данилов Е. А. История русско-хантыйских отношений в памяти юганских хантов // Угры: Материалы VI Сибирского симпозиума «Культурное наследие народов Западной Сибири» (г. Тобольск, 9-11 декабря 2003 г.). Тобольск, 2003. С. 323-326.

6. Домокош П. О фольклоре и эпосе финно-угорских народов // Фольклор и эпос финно-угорских народов: Материалы VIII Международного конгресса финно-угорских писателей (21-23 сентября 2004 г.). Ханты-Мансийск, 2006. С. 18-28.

7. Жулева А. В зеркале нашего времени // Мир Севера. 2008. № 6. С. 46-51.

8. Каксин А. Д. Казымский диалект хантыйского языка. Ханты-Мансийск, 2010.

9. Каргаполов Е. П. Столкновение полярностей, или Сможем ли мы преодолеть идейный и гражданский раскол? // Мир Севера. 2008. № 6. С. 29-37.

10. Косинцева Е. В. Женские образы в хантыйской литературе. Ханты-Мансийск, 2010.

11. Косинцева Е. В., Куренкова Н. В. «Все в этом мире от Бога...»: роман Е. Д. Айпина «Божья Матерь в кровавых снегах». Ханты-Мансийск, 2010.

12. Кульневич С. В., Лакоценина Т. П. Анализ современного урока. Ростов н/Д, 2016.

13. Лагунова О. К. Феномен творчества русскоязычных писателей ненцев и хантов последней трети ХХ века (Е. Айпин, Ю. Вэлла, А. Неркаги). Тюмень, 2007.

14. Лазарев Г.Д. Мы дети одной семьи // Остяко-Вогульская правда. 1938. № 022(925). 28 янв. С. 1-2.

15. Молданова Т. А. Касания Цивилизации // Эринтур: Альманах писателей Югры. 1998. № 3. С. 135171.

16. Нормативные документы по изучению предметной области «Родной язык» // Социальная сеть работников образования nsportal.ru. https://clck.ru/Q4CnH

17. Огрызко В. В. В сжимающемся пространстве: портрет на фоне безумной эпохи. М., 2006.

18. Постановление Правительства Ханты-Мансийского автономного округа - Югры от 19.01.2018 № 11-п «О концепции развития и поддержки чтения в Ханты-Мансийском автономном округе - Югре на 2018-2025 годы». https://clck.ru/Q4DLi

19. Роговер Е. С., Нестерова С. Н. Творчество Еремея Айпина. Ханты-Мансийск, 2007.

20. Рымарева Е.Н., Себелева А. В. Архетипы и мифологемы в литературных мифах Е. Д. Айпина «Масай-богатырь» и М. К. Анисимковой «Танья-богатырь» // Филологические науки. Вопросы теории и практики. 2017. № 6-2(72). С. 49-52.

21. Цымбалистенко Н. В. Север есть Север... Исторические судьбы коренных народов Ямала в литературном освещении. СПб., 2003.

22. Цымбалистенко Н. В. Север учил, ничего не тая... (Творчество Романа Прокопьевича Ругина). Салехард, 2008.

23. Ц Цымбалистенко Н. В. Ямал литературный. От мифологии до постмодернизма. М., 2010.

24. Чепреги М. Сургутский диалект хантыйского языка Ханты-Мансийск, 2017.

25. Шаррен А. В. Некоторые размышления о возрождении народа и о сути литературного творчества. Концепция «Отражения и выражения» (жизнь и творчество Е.Д. Айпина) // Фольклор и эпос финноугорских народов: Материалы VIII Международного конгресса финно-угорских писателей (21-23 сентября 2004 г.). Ханты-Мансийск, 2006. С. 38-43.

26. Шиянова А. А. Парные слова хантыйского языка (на материале шурышкарского диалекта). Тюмень, 2015.

\section{REFERENCES}

1. Belkova, A. E. (2020). Lexical actualization of the conversational style in the structure of the narrative of the Ugric prose writer N. I. Konyaev. Bulletin of Ugric Studies, 10(1), 26-33. (In Russian). https://doi.org/10.30624/2220-4156-2020-10-1-26-33

2. Belkova, A. E. (2018). Specifics of synonymy as a manifestation of nominative variation in Yugra poetry: on the material of creativity of Vladimir A. Mazin. Bulletin of Ugric Studies, 8(1), 15-21. (In Russian). https://doi.org/10.30624/2220-4156-2018-8-1-22-27 
3. Vashchenko, A. (2006). Bremya osobogo roda. In Literaturnaya Rossiya, (37), 23.02.2015, https://litrossia.ru/item/1168-oldarchive/

4. Danilina, G. (1997). Roman E. Aipina "Khanty, ili Zvezda Utrennei Zari”. In Literatura Tyumenskogo kraya, Tyumen, 130-144. (In Russian).

5. Danilov, E. A. (2003). Istoriya russko-khantyiskikh otnoshenii v pamyati yuganskikh khantov. In Ugry: Mat-ly VI Sibirskogo simpoziuma "Kul'turnoe nasledie narodov Zapadnoi Sibiri" (g. Tobol'sk, 9-11 dekabrya 2003 g.). Tobol'sk, 323-326. (In Russian).

6. Domokosh, P. (2006). O fol'klore i epose finno-ugorskikh narodov. In Fol'klor i epos finno-ugorskikh narodov: Mat-ly VIII Mezhdunarodnogo kongressa finno-ugorskikh pisatelei (21-23 sentyabrya 2004 g.), KhantyMansiysk. 18-28. (In Russian).

7. Zhuleva, A. (2008). V zerkale nashego vremeni. Mir Severa, (6), 46-51. (In Russian).

8. Kaksin, A. D. (2010). Kazymskii dialekt khantyiskogo yazyka. Khanty-Mansiysk. (In Russian).

9. Kargapolov, E. P. (2008). Stolknovenie polyarnostei, ili smozhem li my preodolet' ideinyi i grazhdanskii raskol? Mir Severa, (6), 29-37. (In Russian).

10. Kosintseva, E. V. (2010). Zhenskie obrazy v khantyiskoi literature. Khanty-Mansiysk. (In Russian).

11. Kosintseva, E. V., \& Kurenkova, N. V. (2010). "Vse v etom mire ot Boga...": roman E. D. Aipina "Bozh'ya Mater' v krovavykh snegakh". Khanty-Mansiysk. (In Russian).

12. Kul'nevich, S. V., \& Lakotsenina, T. P. (2016). Analiz sovremennogo uroka. Rostov-on-Don. (In Russian).

13. Lagunova, O. K. (2007). Fenomen tvorchestva russkoyazychnykh pisatelei nentsev i khantov poslednei treti XX veka (E. Aipin, Yu. Vella, A. Nerkagi). Tyumen. (In Russian).

14. Lazarev, G. D. (1938). My deti odnoi sem'i. In Ostyako-Vogul'skaya pravda, (022(925)), 28.01.1938, 12. (In Russian).

15. Moldanova, T. A. (1998). Kasaniya Tsivilizatsii. Erintur: Al'manakh pisatelei Yugry, (3), 135-171. (In Russian).

16. Normativnye dokumenty po izucheniyu predmetnoi oblasti "Rodnoi yazyk" https://clck.ru/Q4CnH

17. Ogryzko, V. V. (2006). V szhimayushchemsya prostranstve: portret na fone bezumnoi epokhi. Moscow. (In Russian).

18. Postanovlenie Pravitel'stva Khanty-Mansiiskogo avtonomnogo okruga - Yugry ot 19.01.2018 №11-p "O kontseptsii razvitiya i podderzhki chteniya v Khanty-Mansiiskom avtonomnom okruge - Yugre na 2018-2025 gody" https://clck.ru/Q4DLi sian).

19. Rogover, E. S., \& Nesterova, S. N. (2007). Tvorchestvo Eremeya Aipina. Khanty-Mansiysk. (In Rus-

20. Rymareva, E. N., \& Sebeleva, A. V. (2017). Archetypes and mythologemes in literary myths by E. D. Aipin "Masai-Bogatyr" and M. K. Anisimkova "Tan'ya-bogatyr". Philology. Theory \& practice, (6-2(72)), 4952. (In Russian).

21. Tsymbalistenko, N. V. (2003). Sever est' Sever...: Istoricheskie sud'by korennykh narodov Yamala v literaturnom osveshchenii. St. Petersburg. (In Russian).

22. Tsymbalistenko, N. V. (2008). Sever uchil, nichego ne taya... (Tvorchestvo Romana Prokop'evicha Rugina). Salekhard. (In Russian).

23. Tsymbalistenko, N. V. (2010). Yamal literaturnyi. Ot mifologii do postmodernizma. Moscow. (In Russian).

24. Chepregi, M. (2017). Surgutskii dialekt khantyiskogo yazyka. Khanty-Mansiysk. (In Russian).

25. Sharren, A. V. (2006). Nekotorye razmyshleniya o vozrozhdenii naroda i o suti literaturnogo tvorchestva. Kontseptsiya "Otrazheniya i vyrazheniya" (zhizn' i tvorchestvo E.D. Aipina). In Fol'klor i epos finno-ugorskikh narodov: Mat-ly VIII Mezhdunarodnogo kongressa finno-ugorskikh pisatelei (21-23 sentyabrya 2004 g.). KhantyMansiisk, 38-43. (In Russian).

26. Shiyanova, A. A. (2015). Parnye slova khantyiskogo yazyka (na materiale shuryshkarskogo dialekta). Tyumen. (In Russian).

Себелева А. В., Чернопиская К. А. Особенности профессионального образования в рамках государственного национального проекта по возрождению родных языков и литератур // Вестник Нижневартовского государственного университета. 2020. № 3. С. 86-95. https://doi.org/10.36906/2311-4444/20-3/13

Sebeleva, A. V., \& Chernopiskaya, K. A. (2020). Vocational education within the framework of state national project for revitalization of indigenous languages and literatures. Bulletin of Nizhnevartovsk State University, (3). 86-95. (In Russian). https://doi.org/10.36906/2311-4444/20-3/13 